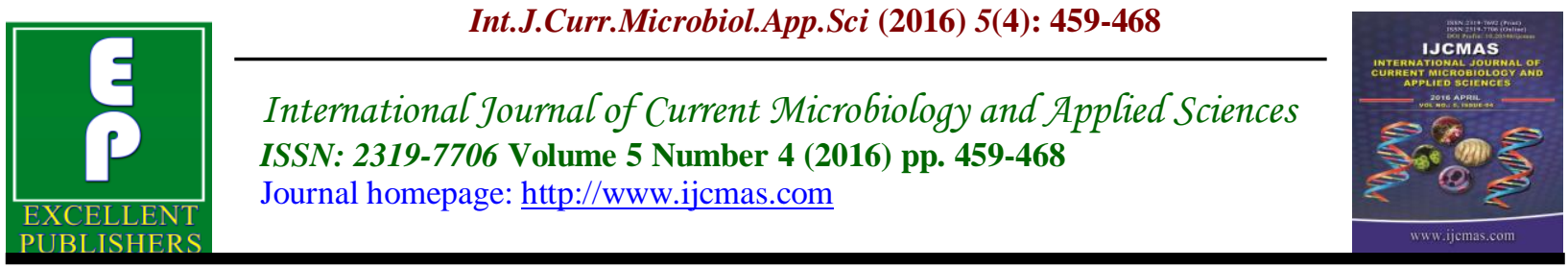

Original Research Article

http://dx.doi.org/10.20546/ijcmas.2016.504.054

\title{
Detection and Genotyping of Giardia lamblia in Clinical and Environmental Samples in Some Regions of Baghdad city
}

\author{
Bedir M.Abbas $^{1}$, Ihsan M. AL-Saqur ${ }^{2}$ and Hadeel A. Majeed $^{1 *}$ \\ ${ }^{1}$ Biology Department, College of Science, Al-Mustansiriya University, Iraq \\ ${ }^{2}$ Technical Lab, Analysis Department, Al-Israa University College, Iraq \\ *Corresponding author
}

\begin{abstract}
A B S T R A C T
Keywords

Giardia lamblia,

Genotyping, infectivity rate, RT-PCR tpi gene.

Article Info

Accepted:

15 March 2016

Available Online:

10 April 2016

The present study was conducted to estimate the prevalence of Giardia lamblia infection in some regions of Baghdad city, the relationship of source of drinking water with the prevalence of this intestinal protozoal parasite had been evaluate, The study revealed that the total rate of G.lamblia infection in humans was 68/375 $(18.13 \%)$ according to three diagnostic methods, there was significant relation $(\mathrm{p} \leq 0.01)$ between infectivity rate $(25 \%)$ of this parasite and persons who consumed tap water as a source of drinking water as compared to other source of drinking water. RT-PCR tpi gene application was able to detected and genotyping G.lamblia to assemblage $\mathrm{A}$ and $\mathrm{B}$, since mix infection of assemblage $(\mathrm{A}+\mathrm{B})$ are more prevalent in fecal samples than others, while in environmental samples the assemblage A, assemblage B showed in 1/4 (25\%), 2/4(50\%) respectively and mixed assemblage $(A+B)$ showed in $1 / 4(25 \%)$ of samples.
\end{abstract}

\section{Introduction}

Giardiasis is the most common parasitic infection of the human intestine worldwide, caused by infection with flagellated, binucleated protozoan parasite G.lamblia, disease ranges in seriousness from asymptomatic, to acute or chronic diarrheal disease associated with abdominal pain and nausea (Halliez and Buret, 2013). G.lamblia (also known as G. duodenalis and G.intestinalis) (Siripattanapipong et al., 2011), First discovered in 1681 by Antonie van Leeuwenhoek (Raza et al., 2013). Genus Giardia contains at least six species that infect animals and/or humans (Ankarklev, 2012), G. lamblia is the only recognized species found in humans and most other mammals including cats, dogs, cattle, pigs, sheep and horses (Raza et al., 2013). A variety of molecular tools, including PCRRFLP and sequence analysis of housekeeping genes, have shown that G.lamblia is a species complex made up of morphologically indistinguishable isolates that are classified into 7 assemblages based on the characterization of the glutamate dehydrogenasa $(g d h)$, small subunit (ssu rRNA), and triose phosphate isomerase (tpi) genes (Nahavandi et al., 2011), these 
assemblages include $\mathrm{A}$ and $\mathrm{B}$, which are potentially zoonotic assemblage A consists of isolates that can be divided into 2 distinct clusters, I and II, assemblage B has been divided into clusters III and IV (Helmy et al., 2009).

Life cycle of G.lamblia has a simple two stages: Infective cysts are ingested with contaminated food or water or by the direct fecal/oral route (Adam, 2001), and trophozoites is vegetative stage live in the upper small intestine where they adhere (Raza et al., 2013). This study aimed to determined the prevalence of giardiasis in some regions of Baghdad, the relationship between giardiasis, the source of drinking water and using molecular approach in detection and genotyping of G.lamblia in fecal and environmental samples.

\section{Materials and Methods}

Clinical Samples were collected from: ALKhadimya Teaching Hospital, Al-Noaaman Hospital and the Laboratories of Medical City for outpatients during the period from the beginning of April 2014 until the end of March 2015, stool samples were collected from 375 patients with gastroenteritis, of both sexes at different ages, and each sample put in a clean screw cup container, labeled with the number, date of collection and request forms which filled for each patient including information about the age, sex and the source of drinking water.

\section{Detection of G.lamblia in Clinical Samples}

The screening for G.lamblia in stool samples under an optical microscope using Lugol'iodine-stained preparation and fresh normal saline smear (Yakoob et al., 2005; Al-Saeed and Issa, 2010), Zinc sulfate flotation method and chromatographic immunological detection (Certest Giardia rapid strip test). The positive samples transfer directly to the molecular lab to conduct the Real Time - polymerase Chain Reaction RT-PCR.

\section{Environmental Samples}

This part of study was performed during the period from beginning of March 2015 till the end of August 2015. Eighteen water samples were collected randomly from some parts of Tigris River located in the study area using polyethylene containers; water samples were taken directly from the surface of the river, the date of collection is recorded for each sample.

\section{Treatment of River Water Samples}

Approximately Twenty liters of river water sample was taken, the sample is left overnight, to precipitate, then got rid the supernatant and took the precipitate which was conducted by a serious of filtration process: filtered through a membrane filter with a pore size of $0.45 \mu \mathrm{m}$. by vacuum pumping system. The solids captured on the filter were removed by rinsed in Phosphate Buffer Saline PBS each $100 \mathrm{ml}$ of PBS contained (20 mg Sodium Dodecyl Sulphate SDS and $20 \mu 1$ Tween 80 ). The rinse water was collected in $50 \mathrm{ml}$ conical centrifuge tube and then centrifuged at $1000 \mathrm{rpm}$ for 10 min, then separated the supernatant about sediment in collection tubes (Nikaeen et al., 2005).

\section{Preservation of Water Sample}

The sample of water (supernatant and precipitate) diluted in $2.5 \%$ potassium dichromate solution and kept at $4 \mathrm{C}^{\circ}$ until subsequent methods.

\section{Molecular Approach}

DNA was extracted from each Giardiapositive stool sample using the QIAamp® 
Stool mini kit (Qiagen, Germany) following the manufacturer's instructions and according to the manufacturer's protocol of Wizard® Genomic DNA Purification Kit supplied by Promega / USA from environmental samples. The purity of DNA was estimated using a Nanodrop Spectrometer. The RT-PCR was used for targeting the tpi gene to detect and genotype $G$. lamblia in clinical samples and environmental samples, the sequence of primers of tpi gene that used in RT- PCR which provided by Alpha DNA, Canada, is tpi A primer, forword (5'- CGA GAC AAG TGT TGA GAT G-3') and reverse (5'- GGT CAA GAG CTT ACA ACA CG-3').The tpi B primer, forword (5'- GTT GCT CCC TCC TTT GTG C-3') and reverse (5'-CTC TGC TCA TTG GTC TCG C-3'). The amplification reactions $(25 \mu \mathrm{l})$ contained $(10 \mu 1)$ of DNA template, PCR working solution which consist of GoTaq ${ }^{\circledR}$ RT-PCR Master Mix is provided as a simple to use, stabilized $2 \mathrm{X}$ master mix that includes all components for quantitative PCR at volume $(12.5 \mu \mathrm{l}), \quad$ G.lamblia forward Primer 10 $\mu \mathrm{M}(1 \mu \mathrm{l})$ G.lamblia reverse Primer $(1 \mu \mathrm{l})$, nuclease free water $(0.5 \mu \mathrm{l})$. Annealing temperature were $55 \mathrm{C}^{0}$ for both primers. The sizes of the DNA amplicons were 576bp region and 208bp region from the $t p i$ $\mathrm{A}$ and tpi $\mathrm{B}$ genes respectively. Following amplification, the PCR products were subjected to melting curve analysis by raising the temperature from 60 to $95^{\circ} \mathrm{C}$ at a rate of $0.2^{\circ} \mathrm{C} / \mathrm{s}$.

\section{Results and Discussion}

The prevalence of G.lamblia estimated in this study at $18.13 \%(68 / 375)$. Many studies considered G.lamblia as one of the most common identified causes of waterborne outbreaks (Nikaeen et al., 2003; Nygård et al., 2006), Giardia cysts have been isolated from water supplies in different parts of the world, over the past 10 years, the contamination of drinking water with Giardia spp. had been recognized (Younas et al., 2008). Study in Baghdad city by AlSaqur et al. (2015) demonstrated scientifically the presence of G.lamblia in tap water which consider the source of drinking water in this city. Therefore, this study focused on the source of drinking water because it is a major source of infection, different types of drinking water were recorded of giardiasis cases (filtrated, bottled, tap and boiled), as showed in table (1) high incidence in persons who drunk tap water 55/220(25\%) compared to other sources of drinking water, there was highly significant relation between the sources of drinking water and the incidence of giardiasis $(\mathrm{p} \leq 0.01)$, low incidence was noticed in patients using the boiling water $3 / 58(5.17 \%)$.

This finding is coincide with the results of Jaeffer (2011) that tap water consumers may be more likely than others to be infect by G.lamblia, as the percentage of giardiasis cases $13,78 \%$ for them. The results of AlSaqur et al. (2015) concerning presence of G.lamblia in tap water at percentage $3.47 \%$ was confirmed the results in current study, that the tap water is probably the source of infection.

Drinking water outbreaks with giardiasis have been reported from Canada, New zealand, Sweden and Germany (Wicki et al., 2009). Study in UK found an association between drinking tap water and giardiasis in persons who had not traveled outside the UK and this result consistent with present finding (Stuart et al., 2003)

There are different causes which may explain the high incidence among consumers of tap water: 
Giardia lamblia cysts relatively resistant to chlorination, particularly if the water is cold, and the amount of chlorine used routinely in drinking water is not sufficient to kill $G$. lamblia (CFSPH, 2012).

Giardia spp. is widely spread in both humans and other mammalian species, permitting for frequent contamination of surface water supplies (Al-Taie and Ali, 2009).

Giardia lamblia cysts are widely distributed in the environment, cysts can penetrate physical barriers in water treatment processes and it disinfectant resistant (Jaffer, 2011).

There are several factors play important roles in the effectiveness of sterilization of water like: temperature, $\mathrm{pH}$ and turbidity of the water, as well as contact time with the chemical materials (CFSPH, 2012).

Giardia lamblia has a low infectious dose for humans (Jaffer, 2011).

The fecal contamination of water and sewer overflows which happened during storm events and discharge raw sewage from sewer pipes into waterways, are common contributors to high fecal pollution levels in urban areas (Hadi and Faraj, 2008).

In Iraq, the amount of tap water which delivered from the native supplies is not enough. So, people are use the water pumps to receive more of water amounts to their homes; this process may be a principal cause of contamination of drinking water with sewage which contain various types of pathogens and may overlap with pollutants and sewage materials that permeate by pumping power to old corroded water pipes (Al-Saqur et al., 2015).

\section{Detection of G.lamblia in Clinical Samples by Real Time PCR (RT-PCR)}

Recent establishment of based quantitative PCR has been advanced in Giardia diagnostics with an increasing success rate in detecting the disease (Ankarklev, 2012). RT-PCR combines the amplification and detection into a single step thereby eliminating the need for any post amplification processing of the sample (Singh et al., 2014). In the present study, RT-PCR was applied to the diagnosis of G.lamblia in clinical specimens, figure (1) clarified the 68 specimens showed positive result for G.lamblia by three detection methods. 63 samples analyzed by RT-PCR. Five samples not being examined by the RTPCR because the amount of DNA were not enough to accomplish, the amplification of tpi gene succeed in 59/63(93.65\%) specimens,

These results agree with Al-kayat (2013) who succeeded in identifying (90.8\%) samples positive for G.lamblia by RT-PCR assay, other study conducted in Canada by Guy in 2004 detected by RT-PCR all specimens that were given positive result for Giardia in microscope 15/15(100\%), and no false negatives were recorded. But current result was much higher compared with results in Egypt by Helmy et al. (2009) who obtained $42.3 \%$ tpi gene amplification rate by same approach. The failure of amplification and given false negative results for some samples may be due to the low quantity of DNA samples, low concentration of DNA, degrading in time, presence of some of PCR inhibitors such as lipid, hemoglobin, cellulose, bile salts, polysaccharides from mucus, bacteria, food degradation product, handling error (AlKayat 2013), and may be reasons related to the primers such as sensitivity of primers (Nantavisai et al., 2007). 
Table.1 The Percentage of Infection According the Source of Drinking Water

\begin{tabular}{|c|c|c|c|c|}
\hline Source of water & $\begin{array}{c}\text { No. } \\
\text { of Infection }\end{array}$ & $\begin{array}{c}\text { No. of } \\
\text { non infection }\end{array}$ & Total cases & $\begin{array}{c}\text { Percentage } \\
\%\end{array}$ \\
\hline Tap water & 55 & 165 & 220 & $* * 25$ \\
\hline Boiling water & 3 & 55 & 58 & 5.17 \\
\hline Filtered water & 5 & 27 & 32 & 15.62 \\
\hline Bottle water & 5 & 60 & 65 & 7.69 \\
\hline Total & 68 & 307 & 375 & 18.13 \\
\hline
\end{tabular}

Table.2 RT-PCR Assays Detection and Genotyping G.lamblia Isolates

\begin{tabular}{|c|c|c|c|c|c|}
\hline $\begin{array}{l}\text { PCR } \\
\text { assay }\end{array}$ & $\begin{array}{c}\text { No. of samples } \\
\text { with } \\
\text { assemblage } A \\
\text { and } \\
\text { percent } \%\end{array}$ & \begin{tabular}{|c|} 
No. of \\
samples with \\
assemblage B \\
and \\
percent \%
\end{tabular} & $\begin{array}{c}\text { No. of } \\
\text { mixed samples } \\
(\mathrm{A}+\mathrm{B}) \\
\text { assemblage } \\
\text { and percent } \%\end{array}$ & $\begin{array}{l}\text { Total and } \\
\text { percent } \%\end{array}$ & $\begin{array}{c}\text { False } \\
\text { negative } \\
\text { samples } \\
\text { and } \\
\text { percent \% }\end{array}$ \\
\hline $\begin{array}{c}\text { RT-PCR } \\
\text { for } 63 \\
\text { positive } \\
\text { samples } \\
\end{array}$ & - & $\begin{array}{c}15 \\
(25.42)\end{array}$ & $\begin{array}{c}44 \\
(74.57)\end{array}$ & $\begin{array}{c}59 \\
(93.65)\end{array}$ & $\begin{array}{c}4 \\
(6.34)\end{array}$ \\
\hline
\end{tabular}

Table.3 Number and Percentage of G.lamblia Assemblage Isolated from Environmental Samples

\begin{tabular}{|c||c||c|c||c|c||}
\hline $\begin{array}{c}\text { RT-PCR } \\
\text { assay }\end{array}$ & $\begin{array}{c}\text { No. of } \\
\text { samples with } \\
\text { assemblage A } \\
\text { and } \\
\text { percent \% }\end{array}$ & $\begin{array}{c}\text { No. of samples } \\
\text { with assemblage } \\
\text { B and percent\% }\end{array}$ & $\begin{array}{c}\text { No. of mixed } \\
\text { samples (A+B) } \\
\text { assemblage } \\
\text { and } \\
\text { percent\% }\end{array}$ & $\begin{array}{c}\text { Total and } \\
\text { percent } \%\end{array}$ & $\begin{array}{c}\text { No. of non } \\
\text { amplified } \\
\text { samples } \\
\text { percent\% }\end{array}$ \\
\hline $\begin{array}{c}\text { RT-PCR for } \\
\text { 7 positive } \\
\text { samples }\end{array}$ & 1 & 2 & 1 & 4 & 3 \\
$(25)$ & $(50)$ & $(25)$ & $(57.14)$ & $(42.85)$ \\
\hline
\end{tabular}


Figure.1 Amplification Curve of Some G.lamblia Isolates from Fecal Samples of Human Detected by RT-PCR, Horizontal Line: Threshold Line

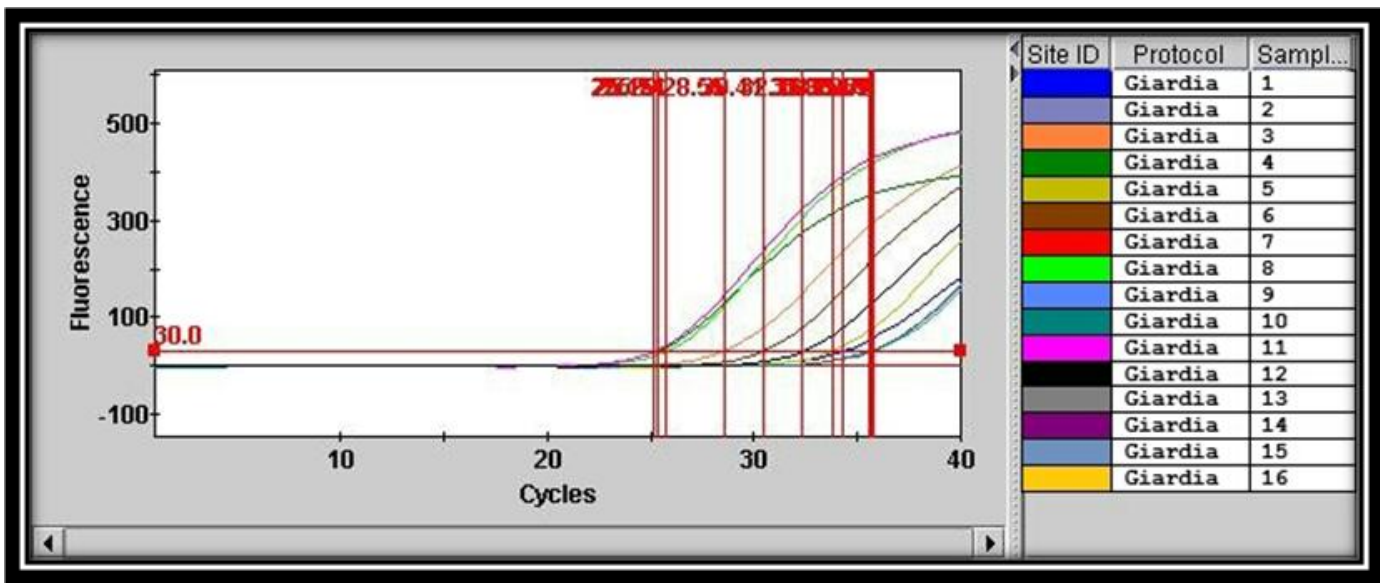

Figure.2 Amplification Curve of 4 G.lamblia Isolates from Environmental Samples Detected by RT-PCR, Horizontal Line: Threshold Line

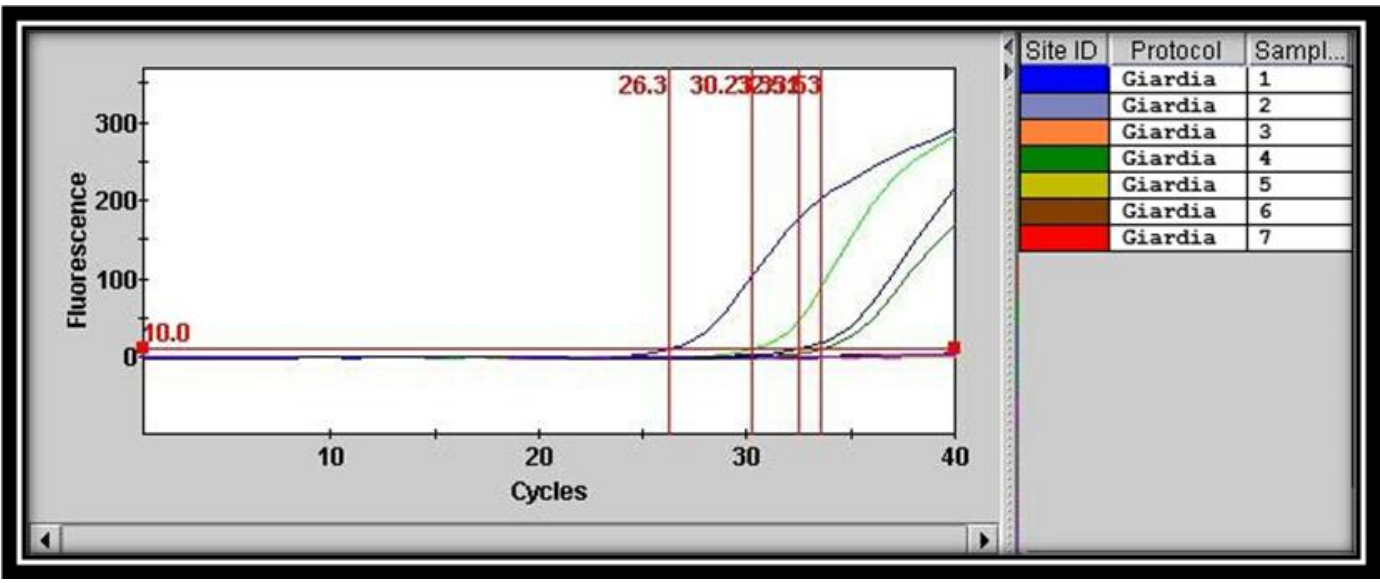

In the RT-PCR assay obtained result demonstrated that the mix infection were predominant where the infection rate of assemblage(A+B) 44/59(74.57\%), while the assemblage $\mathrm{B}$ frequented alone in fifteen cases $(25.42 \%)$, it didn't recorded the cases with assemblage A only, table(2).

The occurrence of mixed infection as shown by the RT-PCR assay in current study may be due to recombination between assemblages $A$ and $B$ which recently suggested, or presence of both types of cysts in the fecal sample (i.e., a mixed infection) and the high sensitivity of RT-PCR enabled to detect the low number of cysts in clinical samples (Al-Meida et al., 2010).

These results agreed with Al-Meida et al. (2010) who showed in their research at the tpi locus of the 10 isolates typed as assemblage A by standard PCR, 9 could be analyzed by RT-PCR, and all were classified as assemblage A plus B similarly, of the 18 isolates typed as assemblage B by standard PCR, analyzed by RT-PCR showed that two 
isolates were classified as assemblage $B$, whereas 16 were $(A+B)$.

Other studies observation were not compatible with the current results, that the majority of clinical samples were assemblage B, such as findings of Amar and colleagues in 2003 by RT-PCR and RFLP analyses of the tpi gene for sub genotyping of G.lamblia . Guy et al.(2004) proved results by RT-PCR Assay for detection and genotype differentiation of G.lamblia in stool specimens, where they noted that percentage of assemblage A was $20 \%$ while assemblage $\mathrm{B}$ was $60 \%$ and mixed specimens of assemblage $(A+B)$ were $20 \%$. In Egypt study conducted by Helmy et al. (2009) who used nested RT- PCR for targeting the tpi gene to detect and genotype G.lamblia in human feces, of the total samples, the percentage of assemblage A $(75.6 \%)$, assemblage $\mathrm{B}(19.5 \%)$ and $(5 \%)$ were mixed of assemblage $(A+B)$.

The results of predominant of assemblage A, $\mathrm{B}$ and mixed infection may be subject to a number of factors; geographic locations of the patients studied, common source of human infection, contamination of public water with raw sewage from animal and human sources (Helmy et al., 2009).

The advantages of using RT-PCR are high sensitivity and specificity, it is able to detected DNA from a single trophozoite or cyst, moreover it could differentiate assemblages A and B of G.lamblia with a sensitivity of detecting an equivalent of one cyst of G.lamblia (Feng and Xiao, 2011). RT-PCR detects reaction progress, speed of analysis and precise measurement of the examined material in the samples (Singh et al., 2014), and the risk of contamination of the samples which may be occurred in conventional PCR may be eliminated by applying the RT-PCR (Adamska et al., 2010).
Detection and Genotyping G.lamblia by RT-PCR Technique in Environmental Samples

The majority of diagnostic methods used in the clinical practice have a limited application regarding the detection of protozoa in water samples, the most important causes restriction is much lower numbers of cysts in water in comparison with material collected from patients (Adamska et al., 2010). Treatment of the water samples had been conducted to reduce the contamination and inhibitors which present in environmental samples, because the efficiency of DNA extraction methods is determined by the DNA recovery rate and PCR inhibitor reduction during DNA extraction (Skotarczak, 2009). In current study the DNA extracted from the environmental samples directly without diagnosed by microscope, the process of extracting DNA succeeded only in seven samples from eighteen samples.

As it was mentioned previously the important route of transmission G.lamblia, is water either drinking water or recreational water and many of waterborne outbreaks of giardiasis happened in world's. In Baghdad the source of tap water that used from the people is Tigris river after series of treatment, in the same time many cases of giardiasis recorded that the contamination water is the cause, and which supports this findings study conducted by Al-Saqur et al. (2015) who scientifically confirmed the presence of Giardia in the water that reaches the houses.

In this study tpiA and tpiB primers that used to identify the G.lamblia in fecal samples used again to detect and genotype G.lamblia only in 7 water river samples, because the process of extracting DNA failed in the remaining eight samples $4 / 7$ (57.14\%), 
three samples given negative results in RTPCR although the process of DNA extraction was successful, all the positive samples for G.lamblia were collected in the summer and autumn season. one of samples represented assemblage A, two samples represented assemblage $B$ and one sample mixed of assemblage (A+B) 25\%,50\%,25\% respectively, table (3) and figure (2).

The failure of amplification of the tpi gene of G.lamblia in environmental samples as compared with other studies (regardless the type of target gene) may be due to that samples are rich in PCR inhibitors, such as humic acids, potassium dichromate, formaldehyde which could be co-extracted with DNA during the isolation and purification process and interfere with the PCR amplification (Skotarczak, 2009), so the recent studies used some materials to avoid the effect of PCR inhibitors such as Bovine Serum Albumin BSA (Anceno et al., 2007), beside low number of cysts in water samples. In general, the diagnosis of Giardia cysts in environmental samples is difficult and requires long time and intensive work and also well professional and experienced personnel (Carmena, 2010)

Current study agree with Guy et al. (2003) who found G.lamblia in 4 environmental water bodies and detected by RT-PCR with bg target gene, they reported in their study the role of some materials in improve the efficiency of PCR and amplified the target gene. In Iran Mahmoudi et al. (2011) demonstrated the presence of Giardia spp. in all 5 water samples from river in north of Iran by nested- PCR with $435 \mathrm{bp}$ fragment of gdh. Anceno et al. (2007) detected and genotyping G.lamblia isolated from surface and waste water in 13 out of 16 samples and all samples tested positive for both assemblages $(\mathrm{A}+\mathrm{B})$ of $G$. lamblia and this is not were consistent with current results about the distribution of assemblage.

\section{References}

Adam, R.D. 2001. Biology of Giardia lamblia. Clin. Microbiol. Rev., 14(3): pp. 474-475.

Adamska, M., Leońska-duniec, A., Maciejewska, A., Sawczuk, M., Skotarczak, B. 2010. Comparison of efficiency of various DNA extraction methods from Cysts of Giardia intestinalis measured by PCR and TAQman real time PCR. Parasite, 17: 299-305.

Al-Khayat, F.A. 2013. Some epidemiological aspects and molecular diagnosis of Giardia duodenalis in human and cattle. Ph.D.Thesis. College of Veterinary Medicine. University of Baghdad, Baghdad, Iraq.

Almeida, A., Pozio, E., Caccio, S.M. 2010. Genotyping of Giardia duodenalis cysts by new real-time PCR assays for detection of mixed infections in human samples. Appl. Environ. Microbiol., 76(6): 1895-1901.

Al-Saeed, A.T., Issa, S.H. 2010. Detection of Giardia lamblia antigen in stool specimens using enzyme-linked immunosorbent assay. EMHJ, 16(4): 362-364.

Al-Saqur, I.M., Mahmood, S.H., Al-Obaidi, H.M.A. 2015. Investigation of Giardia lamblia and other parasites in tap water as a potential source of transmission in some regions of Baghdad. Iraqi J. Sci., 56(1): 337344.

Al-Taie, L., Ali, F.M. 2009. Epidimiology of giardiasis in Sulaimaniya and Chamchamal with its effect on some biochemical parameters and PCV. QMJ, 5(7): 45-53.

Amar, C.F.L., Dear, P.H., Mclauchlin, J. 2003. Detection and genotyping by real - time PCR/ RFLP analyses of 
Giardia from human feces. J. Med. Microbiol., 52: 681-683.

Anceno, A.J., Katayama, H., Houpt, E.R., Petmitr, C.P., Chuluun, B., Shipin, O.V. 2007. IMS-free DNA extraction for the PCR-based quantification of Cryptosporidium parvum and Giardia lamblia in surface and waste water. Int. J. Environ. Health Res., 17(4): 297310.

Ankarklev, J. 2012. Inter and intraassemblage characterization of Giardia intestinalis from clinic to genome. Dissertation for the degree of doctor of philosophy at the University of Uppsala.

Carmena, D. 2010. Waterborne transmission of Cryptosporidium and Giardia: detection, surveillance and implications for public health. In: Mendez-Vilas A, editor., ed. Curr. Res. Technol. Edu. Topics in Appl. Microbiol. Microbial Biotechnol., Badajoz: Formatex, pp 3-14.

Center for Food Security and Public Health [CFSPH]. 2012. Giardiasis. [online]. Available at: www.cfsph.iastate.edu. pp 1-13.

Feng, Y., Xiao, L. 2011. Zoonotic potential and molecular epidemiology of Giardia and Giardiasis. Clin. Microbiol. Rev., 24(1): pp 110-140.

Guy, R.A., Payment, P., Krull, U.J., Horgen, P.A. 2003. Real-Time PCR for quantification of Giardia and Cryptosporidium in environmental water samples and sewage. Appl. Environ. Microbiol., 69(9): pp 51785185.

Guy, R.A., Xiao, C., Horgen, P.A. 2004. Real-Time PCR assay for detection and genotype differentiation of Giardia lamblia in stool specimens. J. Clin. Microbiol., 42(7): pp 33173320.
Hadi, A.M., Farag, A.A. 2008. Distribution of intestinal parasites in drinking water in some regions in Baghdad. Al-Qadisiya J. Vet. Med. Sci., 7(2): pp 33-36.

Halliez, M.C.M., Buret, A.G. 2013. Extraintestinal and long term consequences of Giardia duodenalis infections. World J. Gastroenterol., 19(47): pp 8974-8985.

Helmy, M.M.F., Abdel-Fattah, H.S., Rashed, L. 2009. Real-Time PCR/RFLP Assay to Detect Giardia intestinalis Genotypes in Human Isolates with Diarrhea in Egypt. $J$. Parasitol., 95(4): pp 1-5.

Jaeffer, H.S. 2011. Prevalence of Gairdia lamblia and Entamoeba histolytic /Entamoeba dispare infections among children in Al-Shulaa and Alkhadimya -Baghdad -Iraq. JUAPS, 5(2): pp 6-10.

Mahmoudi, M.R., Ashrafi, K., Abedinzadeh, H., Tahvildar-Bideruni, F., Haghighi, A., Bandehpour, M., Lailabadi, N.T., Kazemi, B. 2011. Development of sensitive detection of Cryptosporidium and Giardia from surface water in Iran. Iranian $J$. Parasitol., 6(3): pp 43-51.

Nahavandi, K.H., Fallah, E., Asgharzadeh, M., Mirsamadi, N., Mahdavipour, B. 2011. Glutamate dehydrogenase and triosphosphate isomerase coding genes for detection and genetic characterization of Giardia lamblia in human feces by PCR and PCRRFLP. Turk. J. Med. Sci., 41(2): pp 283-289.

Nantavisai, K., Mungthin, M., Tan-ariya, P., Rangsin, R., Naaglor, T., Leelayoova, S. 2007. Evaluation of the sensitivities of DNA extraction and PCR methods for detection of Giardia duodenalis in stool 
specimens. J. Clin. Microbiol., 45(2): pp 581-583.

Nikaeen, M., Mesdaghinia, A.R., Tehrani, M.J., Rezaian, M., Vaezi, F. 2003. Sensitive Detection of Giardia cysts by Polymerase Chain Reaction (PCR). J. Publ. Health., 32(1): pp 15-18.

Nikaeen, M., Mesdaghinia, M., Tehrani, M., Rezaeian, M., Makimura, K. 2005. A Nasted - PCR Assay for Detection of Cryptosporidium parvum Oocysts in Water Samples. Iranain J. Publ. Health, 34(1): pp 13-18.

Nygard, K., Schimmer, B., Sobstad, O., Walde, A., Tveit, I., Langeland, N., Hausken, T., Aavitsland, P. 2006. A large community outbreak of waterborne giardiasis-delayed detection in a non-endemic urban area. BMC Public Health, 6: 141.

Raza, A., Iqbal, Z., Muhammad, G., Hanif, K., Khan, M.A. 2013. Giardiasis. Rev. Vet. Ani. Sci., 1(1): pp 15-20.

Singh, J., Birbian, N., Sinha, S., Goswami, A. 2014. A critical review on PCR, its types and applications. Int. J. $A d v$. Res. Biol. Sci., 1(7): pp 65-80.

Siripattanapipong, S., Leelayoova, S., Mungthin, M., Thompson, R.C.A., Boontanom, P., Saksirisampant, W., Tan-ariya, P. 2011. Clonal diversity of the glutamate dehydrogenase gene in Giardia duodenalis from Thai isolates: evidence of genetic exchange or mixed Infections. $B M C$ Microbiol., 11(206): pp 4-11.

Skotarczak, B. 2009. Methods for parasitic protozoans detection in the environmental samples. Parasite, 16: pp 183-190.

Stuart, J.M., Orr, H.J., Warburton, F.G., Jeyakanth, S., Pugh, C., Morris, I., Sarangi, J., Nichols, G. 2003. Risk factors for sporadic giardiasis: a case-control study in south western England. Emerg. Infect. Dis., 9(2): pp 229-233.

Wicki, M., Svoboda, P., Tanner, M. 2009. Occurrence of Giardia lamblia in recreational streams in BaselLandschaft, Switzerland Environ Res; Article in press. Doi:10.1016/j.envres.02.012.

Yakoob, J., Jafri, W., Abid, S., Jafri, N., Hamid, S., Shah, H.A., Rizvi, L., Islam, M., Shaikh, H. 2005. Giardiasis in patients with dyspeptic symptoms. World J. Gastroenterol., 11(42): pp 6667-6670.

Younas, M., Shah, S., Talaat, A. 2008. Frequency of Giardia lamblia infection in children with recurrent abdominal pain. JPMA, 58(4): 171174.

\section{How to cite this article:}

Bedir M.Abbas, Ihsan M. AL-Saqur and Hadeel A. Majeed. 2016. Detection and Genotyping of Giardia lamblia in Clinical and Environmental Samples in Some Regions of Baghdad city. Int.J.Curr.Microbiol.App.Sci.5(4): 459-468. doi: http://dx.doi.org/10.20546/ijcmas.2016.504.054 